\title{
FINANCIAL FEASIBILITY ANALYSIS OF SMALL-SCALE FISH SMOKING BY FISHERMAN IN HOME INDUSTRIES
}

\author{
Intyas Candra Adi ${ }^{\star}$, Tjahjono Agus, Fattah Mochammmad \\ Faculty of Fisheries and Marine Science, University of Brawijaya, Indonesia \\ *E-mail: candra.intyas@gmail.com
}

\begin{abstract}
This research analyzed the profitability of fish smoking in small-scale home industries in Indonesia, and compared businesses run by members and non-members of the business organization Poklashar. Samples were selected using multi-stage cluster sampling. A profitability analysis was carried out by calculating R/C, BEP, net profit and RTC, and the financial feasibility was measured by the NPV, B/C, IRR and PBP. The results of this research showed that home industries run by members of Poklashar had higher profitability and stronger financial feasibility than those of non-members. This was because members received capital loans, business training, management improvement training, and improved marketing strategies from the government, resulting in higher product value.
\end{abstract}

\section{KEY WORDS}

Profitability, financial feasibility, small-scale fisherman, smoked business.

Fishery resources are a common property and many parties are attracted to the exploitation of marine products. This has intensified competition and made the market more open. The data released by CTF (2014) showed that fisheries in Indonesia were dominated by small-scale capture fisheries, which comprised up to $87.5 \%$ of the total players. This domination by small-scale fishing is despite its low productivity, caused by the use of traditional equipment. This low productivity means that fishermen generally live below the poverty line.

Poverty in fishing communities consists of structural poverty (poverty resulting from a social structure that tends to give more benefit to big fishermen (capital owners)), cultural poverty (poverty caused by cultural factors that are not supportive of business progress), and natural poverty (which is due to environmental conditions). One of the major factors that influence structural poverty among fishing communities is the role of institutions, which includes marketing institutions and production institutions (Tain, 2011).

Factors that contribute to the high poverty rate of fishing communities include: (1) the use of traditional fishing equipment / technology, (2) the small scale of the businesses, (3) inefficient product marketing strategies, and (4) the lack of relevant skills among fishermen, most of whom are laborers (Directorate General of Coastal and Small Islands, 2005). This lack of skills means that fishermen are only able to increase their income by performing basic fishery product processing. According to Heruwati (2002), traditional processing methods, such as drying, scanning, smoking, salting, or fermentation into paste (including shrimp paste) are preferred to modern methods. Small-scale fishing applies traditional processing methods, especially smoking, that are often carried out at home. According to Mareta and Awami (2011), smoking is a method of preserving / processing fish using smoke from burning wood charcoal, coconut shells, coir, sawdust or rice husks.

There are two fish-smoking methods: hot smoking and cold smoking. In hot smoking, fish are placed close to the source of smoke and are smoked within a short time. During the hot smoking process, the fish absorb the smoke and are quickly cooked, while its water content remains high. In cold smoking, fish are placed on shelves or hung away from the source of smoke. The cold smoking process takes up to two weeks (Kadir, 2004). Fishermen in Tasikmadu Village, who were the subjects of our study, mostly used hot smoking.

Strengthening the role of economic institutions in local fishing communities might help to alleviate the structural poverty in these communities. In Indonesia, the Independent 
Community Empowerment Program is one of the National Development Programs carried out by PNPM Mandiri. It is realized in the form of a program called Rural Mina Business Development (PUMP) to provide capital funding for businesses owned by fishermen / cultivators $(K U B)$, and for processing and marketing (Poklashar) to be able to initiate the establishment of fishery cooperatives (KKP, 2011), to address problems related to structural poverty. Establishing a cooperative business networking system for community-based businesses requires the development of qualified human resource who have adequate competence. This development includes: (1) improvements in institutional competency, through understanding the purpose of cooperatives, (2) improvements in business and managerial competency, (3) increased understanding of science and technology, (4) better networking skills, (5) increased competency in program development and the creation of business competition excellence in cooperatives, and (6) increased competency in service optimization (Nurhayati, 2011).

In light of this information, the research objective in this study was to analyze the level of profitability and financial viability of small-scale fishing households with fish-smoking businesses, comparing members and non-members of Poklashar.

\section{METHODS OF RESEARCH}

This research employed a case study research design. According to Nazir (2003), a case study is a study to investigate the status and personality of research subjects. Research subjects in a case study can be individuals, groups, institutions or communities. Case studies provide a detailed description of the typical background, traits and characteristics of the case or status of the research subject, which results can be then generalized to broader scope.

In this research, multi-stage cluster sampling was employed to select the samples because the population was high and there were difficulties in reaching them (requiring considerable time and costs). The cluster sampling technique was used to classify units of analysis in the population into groups, called clusters, from which samples were selected. The number of groups taken as samples was randomized for every element in the cluster. Sampling was done in stages: the population was divided into a first level group, from which a second level group was determined and so on (Singarimbun, 1987).

The first cluster included regions that have many small fishing boats with outboard motors that have a minimum power of 6 PK. Trenggalek District was chosen as the first cluster as it had the highest number of fishing fleets, reaching up to 9,656 people. The second cluster was chosen by selecting sub-districts where fishermen could represent the diversity of conditions. Watulimo District was chosen as it was found that the area had the highest number of fishermen (6,897 in 12 villages). The third stage selection was based on regions with the largest number of fish-smoking business units and Tasikmadu Village with ten business units (Poklashar) was selected. Surveys were done to select the members of business units (Poklashar). From the survey, eight respondents were selected, four of whom were members of the organization Poklashar and four who were not members.

The data obtained were quantitatively analyzed using profitability and financial feasibility analyses. According to Hanum (2012), profitability refers to a company's ability to generate profits that will be used for present and future predictions. Profitability plays an important role for a company as high profitability enables a company to pay all obligations and remain liquid. Profitability analysis in this study was carried out by calculating R/C, BEPs, BEPq net income and return to total capital (RTC) value.

Total Revenue (TR) was obtained by multiplying the produced product (Q) by the sales price $(\mathrm{P})$ :

$$
T R=P \times Q
$$

Where: $T R=$ Total Revenue $(R p) ; P=$ Product Price $(R p / k g) ; Q=$ Amount of Sold Product (kg).

Total Cost (TC) was obtained from summing the fixed cost (FC) and variable cost (VC): 


$$
\mathrm{TC}=\mathrm{FC}+\mathrm{VC}
$$

Where: $T C=$ Total Cost $(R p) ; F C=$ Fixed Cost $(R p)$; VC = Variable Cost $(R p)$.

$\mathrm{R} / \mathrm{C}$ analysis compares the annual relative profit of a company to its operational costs. A company makes profit if $R / C$ is greater than 1 (Effendi and Oktariza, 2006). R/C was calculated as follows:

$$
\frac{R}{C}=\frac{T R}{T C}
$$

Where: $\mathrm{TR}=$ Total Revenue $(\mathrm{Rp}) ; \mathrm{TC}=$ Total Cost $(\mathrm{Rp})$.

BEP refers to the number of units to be sold or the minimum income that should be obtained to return the investment made (i.e. total revenue and total cost are equal). If total revenue or total production is greater than the break-even point, profit is made. BEP was calculated as follows.

$$
B E P_{S}=\frac{F C}{1-\frac{V C}{T R}}
$$

Where: FC = Fixed Cost (Rp); VC = Variable Cost $(\mathrm{Rp}) ; \mathrm{TR}=$ Total Revenue $(\mathrm{Rp})$.

Nicholson (1999) defined net profit as the amount of income after removing the operational costs (fixed costs and variable costs).

$$
\pi=\mathrm{TR}-\mathrm{TC}
$$

Where: $\pi=$ Net Profit $(R p) ; T R=$ Total Revenue (Rp); TC = Total Cost (Rp).

RTC analysis was conducted to determine the profitability level of all resources used in business operational activities. RTC was then compared to the loan interest set by banks (Soekartawi, 1986). RTC was calculated because respondents employed their family members in production activities. To calculate the return obtained by small-scale fishing, RTC was calculated as follows:

$$
R T C=\frac{\pi-N K K}{\text { Total Capital }} \times 100 \%
$$

Where: $\pi=$ Net Profit $(R p)$; NKK = Work Value of the Relatives (Rp).

An RTC value is considered good if it exceeds the rate of micro loan interest without being compared with the opportunity cost of capital. The rate of loan interest that applied when this research was conducted was $17.50 \%$ (BRI, 2016).

Financial feasibility analysis was conducted by measuring the NPV, B/C, IRR and PP. NPV is the difference value between PV of benefit flows and PV cost flows (Gray C. et al., 2001). NPV measures the time value money and gives inconsistent interpretation (Campoa and Sergio, 2017). If the NPV is positive, the company is considered to be profitable. The following was the formula used to calculate NPV (Husnan and Suwarsono, 2014):

$$
N P V=-A_{0}+\sum_{t=1}^{n} \frac{A_{t}}{(1+i)^{t}}
$$

Where: $A_{0}=$ Investment expenditure in year $0(R p) ; A_{t}=$ Net cash inflows in year $t(R p)$; $\mathrm{i}=$ Interest rate $(\%) ; \mathrm{n}=$ Economic life of the project (year).

$\mathrm{B} / \mathrm{C}$ is a comparison between the present value and the net cash income in the future from the present investment (Husnan and Suwarsono, 2014). An investment is considered profitable if the $B / C$ value is greater than 1 (Rangkuti $F ., 2012$ ). $B / C$ was measured using the following formula:

$$
\frac{B}{C}=\frac{\sum_{t=1}^{n} \frac{B_{t}}{(1+i)^{t}}}{\sum_{t=1}^{n} \frac{C_{t}}{(1+i)^{t}}}
$$


Where: $\mathrm{B}_{\mathrm{t}}=$ Gross income in year $\mathrm{t}(\mathrm{Rp}) ; \mathrm{Ct}=$ Gross cost in year $\mathrm{t}(\mathrm{Rp}) ; \mathrm{n}=$ Economic life of the project (year); $i=$ Interest rate $(\%)$.

IRR is the discount rate that sets the net investment value (Gray C. et al., 2001). If the interest rate of IRR is higher than the targeted profit, a company is considered profitable (Husnan and Suwarsono, 2014). IRR was calculated as follows:

$$
I R R=i_{1}+\frac{N P V_{1}}{N P V_{1}-N P V_{2}}\left(i_{2}-i_{1}\right)
$$

Where: $\mathrm{NPV}_{1}=\mathrm{NPV}$ with positive value (Rp); $\mathrm{NPV}_{2}=\mathrm{NPV}$ with negative value (Rp); $\mathrm{i}_{1}=$ Interest rate when NPV is positive (\%); $\mathrm{i}_{2}=$ Interest rate when NPV is negative (\%).

PP refers to the length of time needed by investors to pay back all investment costs (Rangkuti F., 2012). When the PP of a company is shorter than the predetermined PP, the company is considered to be profitable (Husnan and Suwarsono, 2014). PP was calculated using the following formula:

$$
P P=\frac{A_{0}}{\pi}
$$

Where: $A_{0}=$ Investment expenditure in year $0(R p) ; \pi=$ Net revenue $(R p)$.

\section{RESULTS AND DISCUSSION}

The financial aspects of a business are the key to business feasibility studies because, if the financial aspects are weak, the proposed project will be rejected as it will not provide significant economic benefits (Hapsari et al, 2017). Economic evaluation is commonly carried out to optimize the use of financial resources and help policymakers determine future strategies and make proper investment decisions (Das et al, 2013). The capital needed in the fish-smoking business consists of fixed capital and working capital. According to Warouw, et al (2016), working capital is the most important aspect of a business because it determines the success of short-term operational activities that affect the amount of earned revenue.

In this study, fixed capital (fixed assets) in the fish-smoking business included knives, buckets, eggs, freezers, sea cucumbers, cool boxes, fans, brushes and plastic containers, fish sealers and cleaning tools, grills, and draining tables. The working capital consisted of current capital (current assets) and depreciation of equipment. Current capital included labor costs, fuel-wood, cooking oil, coconut fiber, tweezers, plastic, oil paper, ice, newsprint, spices, hygiene care, vehicle rental, and equipment maintenance. The following data of capital, revenue and cost of smoked fish home industries can be seen in Table 1 below.

It can be seen in table 1, Group 1 consisted of small-scale fishermen who were members of the business organization Poklashar, while those in Group 2 were also smallscale fishermen but were not members of Poklashar. It can be seen in Table 1 that the average total business capital of fishermen in Group 1 was $\mathrm{Rp} 135,387,326$ / year, with fixed capital of $R p$ 4,647,250 / year and working capital of Rp 130,740,076 / year, while for nonmembers the corresponding amounts were Rp 115,093,933 / year, Rp 1,586,750 / year and Rp 113,507,183 / year, respectively. Fisherman in Group 1 received financial assistance (loans) from the government through business institutions, for items such as freezers, cool boxes, stainless steel tables, and grill tools. Their fixed capital was greater than that of fishermen Group 2.

The average income of fishermen in Group 1 was Rp 193,440,000 / year with a selling

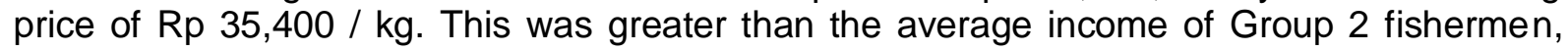
which was Rp 147,600,000 / year with a selling price of Rp 32,000 / kg. Fishermen in Group 1 (members of Polkashar) were provided with a sales location facility in a tourist area (Prigi beach). They had more and more diverse, customers, while the fishermen in Group 2 sold their products in the market or to neighbors. 
The average total business costs (fixed costs and variable costs) incurred by fishermen in Group 1 amounted to Rp 130,740,076 / year, which was greater than those of the fishermen in Group 2 (113,507,183 / year).

Table 1 - Annual, Average Capital, Revenue, and Operational Costs of Smoked Fish Home Industries in Tasikmadu Village, Watulimo Sub-district

\begin{tabular}{lllll}
\hline No & Data & Unit & 1 & 2 \\
\hline 1 & Capital & & & \\
& Fixed Capital & Rp/year & $4,647,250$ & $1,586,750$ \\
& Working Capital & Rp/year & $130,740,076$ & $113,507,183$ \\
& Total Capital & Rp/year & $135,387,326$ & $115,093,933$ \\
2 & Revenue & & & \\
& Amount of Fish & $\mathrm{kg} /$ year & 4,740 & 5,490 \\
& Fish Selling Price & $\mathrm{Rp} / \mathrm{kg}$ & 35,400 & 32,000 \\
& Total Revenue & Rp/year & $193,440,000$ & $147,600,000$ \\
3 & Production Cost & Rp/year & $4,589,626$ & $3,476,433$ \\
& Fixed Cost & Rp/year & $126,150,450$ & $110,030,750$ \\
& Variable Cost & Rp/year & $130,740,076$ & $113,507,183$ \\
& Total Cost & &
\end{tabular}

Note: 1. Small-scale fishermen who are members of the business organization Poklashar; 2. Small-scale fisherman who are not members of Poklashar.

Table 2 - Annual Profitability and Financial Feasibility of Fish-Smoking Home Industries in Tasikmadu Village, Watulimo Sub-district

\begin{tabular}{llll}
\hline Analysis & Unit & 1 & 2 \\
\hline Profitability & & & \\
R/C & & 1.48 & 1.30 \\
BEPs & Rp. & $13,193,984$ & $13,658,018$ \\
BEPq & $\mathrm{kg}$ & 522.38 & 285.26 \\
Net Revenue & $\mathrm{Rp}$. & $62,699,924$ & $34,092,817$ \\
RTC & $\%$ & 41 & 20 \\
Financial Feasibility of df $12 \%$ in 10 years & & $77,538,087$ \\
NPV & Rp. & $218,881,228$ & 1.67 \\
B/C & $\%$ & 2.62 & 27 \\
IRR & $\%$ & 45 & 3.4 \\
PP & Year & 2.2 & \\
\hline
\end{tabular}

Note: 1. Small-scale fishermen who are members of the business organization Poklashar; 2. Small-scale fisherman who are not members of Poklashar.

It can be seen in Table 2 that the ratio of gross income to total costs $(R / C)$ for both groups of fishermen was greater than 1, and so business in both groups was profitable. The break-even point during non-profitable conditions will not get smaller if the net income equals the variable cost. Both groups exceeded the BEPq and the revenues obtained by the two groups were also greater than the BEPs, indicated that the businesses were profitable. The difference between gross income and total costs gives the net income. Both groups generated positive net income, so the businesses were considered profitable. The ratio of net income to total capital issued gives the level of profitability or RTC. The value of RTC was found greater than the rate of loan interest of $17.5 \%$, implying that the fish-smoking businesses carried out by both groups were feasible.

According to Das et al (2013) and Muhammad et al. (2016), investment feasibility is shown by a positive NPV, a B/C ratio greater than 1 at all discount rates, and an IRR greater than the discount factor. Table 2 shows that the financial feasibility in ten years, with a discount factor (df) of $12 \%$ for both business groups, had positive NPV values. For groups, the $\mathrm{B} / \mathrm{C}$ ratios were greater than 1 , the IRR values were greater than the discount factor $(12 \%)$, and the return on capital was below five years, implying that the businesses were profitable and feasible to run. If both groups are compared, the businesses run by members of Poklashar were considered more profitable and feasible than those run by non-members of Poklashar. 
Sensitivity analysis was used to evaluate the impact on the business by predicting possible optimistic and pessimistic conditions (Oraee K. et al, 2011). The sensitivity analysis was carried out based on an assumption of decreasing revenues and increasing costs. Decline in revenue could be caused by changes in consumer preference away from smoked fish products, leading to a decrease in product demand. Higher costs were assumed to be triggered by increases in the price of raw materials or the price of complementary goods, which affect the production cost. The capability of businessmen to cope with market dynamicity such as lower demand among Poklashar member fishermen reached $20.26 \%$, while the one of non-Poklashar members was $9.311 \%$. Poklashar members showed $30.71 \%$ better ability in dealing with higher costs compared to the one of non-Poklashar members which was only $12.48 \%$. Decreases and increases in costs have exceeded the maximum limit, where loss occurred in NPV, B / C, IRR and PP.

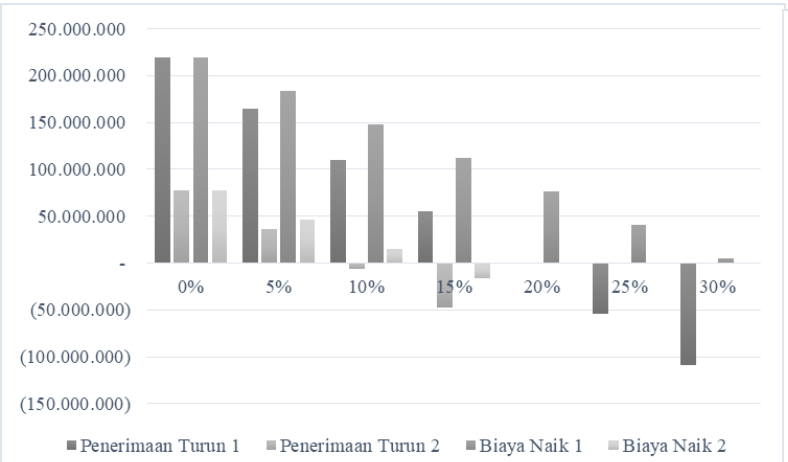

(a). NPV Sensitivity

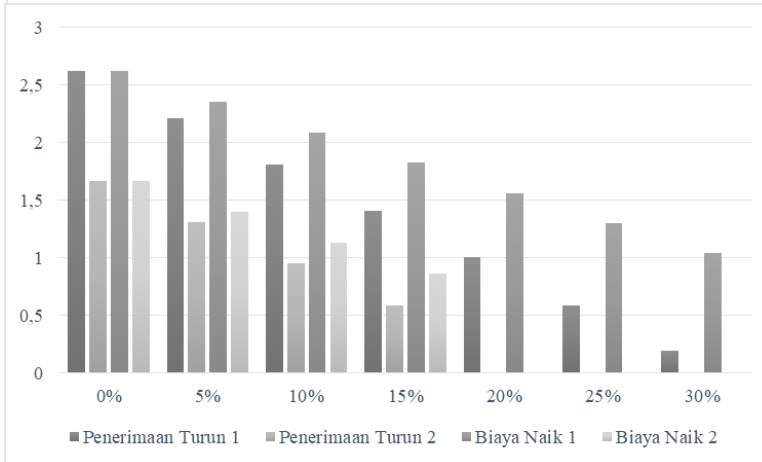

(b). B/C Sensitivity

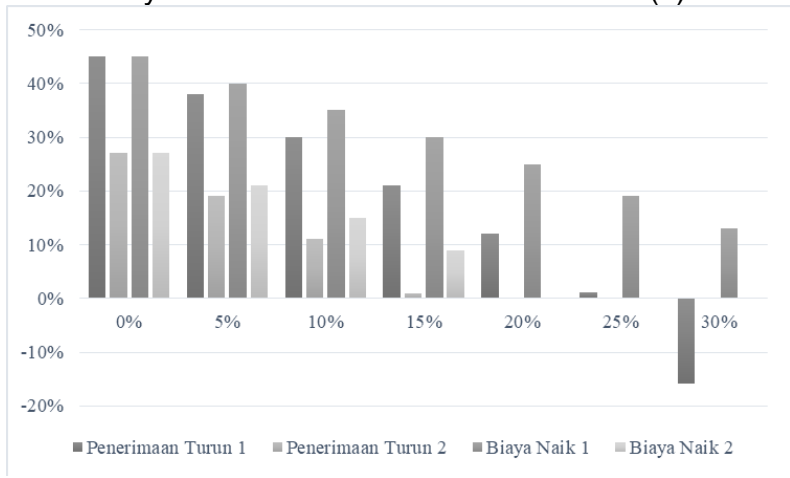

(c). IRR Sensitivity

Figure 1 - Sensitivity Analysis of the Financial Feasibility

Non-members of Poklashar were rather more sensitive towards changes than the members because lower revenue and a slight increase in costs led to negative results. These results showed that the Poklashar organization contributed to the changes in profitability for fish-smoking businesses.

\section{CONCLUSION}

The government program done by establishing Poklashar has encouraged an increase in profitability and financial feasibility in $100 \%$ of all fish fumigation business. Small-scale fishermen who were members of the organization could access capital loans, business training, enhancement of business management and improvement in marketing access from the Government that they obtained higher economic value. Suggestions have been proposed based on the results of this research (1) fishermen are recommended to register as members of Poklashar in order to have better profitability and (2) government and other related parties are expected to provide supports in establishing Poklashar cooperatives if Poklashar runs well. 


\section{REFERENCES}

1. Campoa S.R. and Sergio Z. 2017. Reviewing capital cost estimations in aquaculture. Aquaculture Economics \& Management, http://dx.doi.org/10.1080/13657305.2017. 1300839: 1-22.

2. Das A., Nalini R. K., Krishnan and Vinod K.Y. 2013. Economic viability of Aqua-Model Village Scheme: a case study in West Tripura District. Indian J. Fish. 60(3): 41-46.

3. Ditjen Pesisir and Pulau-Pulau Kecil. 2005. Ditjen P3K Lakukan Penyusunan Indikator Kesejahteraan Masyarakat Pesisir.

4. Effendi I. and Oktariza W. 2006. Manajemen Agribisnis Perikanan. Penebar Swadaya, Jakarta.

5. Gray C., Payaman S., Lien K.S., P.F.L Maspaitella and R.C.G. Varley. 2002. Pengantar Evaluasi Proyek. PT Gramedia Pustaka Utama, Jakarta.

6. Husnan S. and Suwarsono M. 2014. Studi Kelayakan Proyek Bisnis. UPP STIM YKPN, Yogyakarta.

7. Hanum, Zulia. 2012. Pengaruh Profitabilitas Terhadap Modal Kerja pada Perusahaan Makanan and Minuman yang Terdaftar di Bursa Efek Indonesia. Jurnal Manajemen and Bisnis, 11(2): $1-15$.

8. Hapsari T.D., Bogi B.J., Aristi D.P.F. and Triarso I. 2017. Business Profile of Boat Lift Net and Stationary Lift Net Fishing Gear in Morodemak Waters Central Java. IOP Conf. Series: Earth and Environmental Science 116 (2018) 012022 doi:10.1088/17551315/116/1/012022.

9. Heruwati, Endang Sri. 2002. Pengolahan Ikan Secara Tradisional: Prospek and Peluang Pengembangan. Jurnal Litbang Pertanian 21(3): 92 - 99.

10. Kadir L. 2004. Pengaruh Suhu and Lama Penyimpanan Terhadap Jumlah Kandungan Bakteri and Kualitas Fisik Ikan Tongkol Asap (Euthynnus Afinis). JBP 6: 79-84.

11. Kementrian Kelautan and Perikanan. 2011. Peraturan Menteri Kelautan and Perikanan Republik Indonesia Nomor Per.41/Men/2011.

12. 2014. Kelautan and Perikanan Dalam Angka 2014. Pusat Data Statistik and Informasi, Jakarta.

13. Mareta, Dea Tio and Awami, Nur Shofia. 2011. Pengawetan Ikan Bawal dengan Pengasapan and Pemangga- -ngan. Mediagro. 7(2): 33 - 47.

14. Muhammad H, Situmorang ML, Djohan YA, Aditiawati P, Suantika G (2016) Biological, Technical, and Financial Feasibilities Study of Zero Water Discharge (ZWD) System Application in Low Salinity White Shrimp (Litopenaeus vannamei Boone) Urban Aquaculture, Study Case: Gresik District, East Java, Indonesia. J Fisheries Livest Prod 4: 197. doi: 10.4172/2332-2608.1000197.

15. Nazir, Moh Ph.D. 2003. Metode Penelitian. PT Ghalia Indonesia, Jakarta.

16. Nicholson, Walter. 1999. Mikro Ekonomi Intermediates and Aplikasinya. Eighth Edition. Translated by IGN Bayu Mahendra \& Abdul Aziz. Penerbit Erlangga, Jakarta.

17. Nurhayati, Popong. 2004. Nilai Tambah Produk Olahan Perikanan Pada Industri Perikanan Tradisional di DKI Jakarta. Buletin Ekonomi Perikanan. 5(2): 17-23.

18. Oraee K., Sayadi A. R. and Tavassoli S.M.M. 2011. Economic evaluation and sensitivityrisk analysis of Zarshuran gold mine project. SME Annual Meeting Feb. 27-Mar. 02, 2011: 1-6.

19. Rangkuti F. 2012. Studi Kelayakan Bisnis \& Investasi. PT Gramedia Pustaka Utama, Jakarta.

20. Singarimbun, M. Effendi, S. 1987. Metode Penelitian Survei. Penerbit LP3ES, Jakarta.

21. Soekartawi et al. 1986. IImu Usahatani and Peneitian untuk Pengembangan Petani Kecil. Universitas Indonesia Press, Jakarta.

22. Tain, Anas. 2011. Penyebab Kemiskinan Rumah Tangga Nelayan Di Wilayah Tangkap Lebih Jawa Timur. Jurnal Humanity. 7(1): $1-10$.

23. Warouw, Christiana, Nangoy, Sintje and Saerang, Ivonne S. 2016. Pengaruh Perputaran Modal Kerja and Profitabilitas Terhadap Nilai Perusahaan pada Perusahaan Farmasi di Bursa Efek Indonesia. Jurnal Berkala Ilmiah Efisiensi. 16(2): 366 - 375. 